\title{
IN VITRO ANTIBACTERIAL EFFECT OF EUTERPE OLERACEA MART. AND THEOBROMA GRANDIFLORUM HYDROALCOHOLIC EXTRACTS
}

(Efeito antibacteriano In vitro de extratos hidroalcoólicos de Euterpe oleracea Mart. $E \underline{\text { Theobroma grandiflorum) }}$

Lew Kan Sprenger, Elane Guerreiro Giese, Jeannie Nascimento dos Santos, Marcelo Beltrão Molento ${ }^{1}$

${ }^{1}$ Correspondência: molento@ufpr.br

RESUMO: Este estudo avaliou o potencial antimicrobiano in vitro destas espécies contra estirpes de bactérias Gram-positivas e Gram-negativas. Os extratos hidroalcoólicos foram preparados a partir das folhas, polpa e sementes secas, de Euterpe oleracea Mart. e Theobroma grandiflorum por percolação contínua com álcool etílico $70 \%$. A atividade antimicrobiana foi avaliada frente a quatro microrganismos pelo método de difusão em disco e ensaio de concentração inibitória mínima (CIM). A atividade antimicrobiana mostraram que extratos de polpa e sementes de açaí possuiram inibição significativa, respectivamentem em Clostridium perfringens (320 e $640 \mathrm{CIM}$ ), Staphylococcus aureus (80 e $320 \mathrm{CIM}$ ) e Pseudomonas aeruginosa (640 e 2560). Extratos de cupuaçu não mostraram nenhum efeito sobre todas as bactérias. O uso fitoterápicos de açaí pode ser uma alternativa sustentável, viável e acessível para o tratamento antimicrobiano. Novos estudos devem ser realizados buscando melhores resultados nos extratos de açaí e novas formulações do extratos de cupuaçu.

Palavras-chave: açaí, antimicrobiano, cupuaçu, fitoterápicos

ABSTRACT: This study evaluated the in vitro antimicrobial activity of these species against strains of Gram-positive and Gram-negative bacteria. The hydroalcoholic extracts were prepared from dried leaves, pulp and seeds of $E$. oleracea Mart. and T. grandiflorum by continuous percolation with $70 \%$ ethyl alcohol. The antimicrobial activity was evaluated against four microorganisms by the agar disc diffusion method and the minimal inhibitory concentration (MIC) assay. The antimicrobial activity showed that the açai pulp and seeds possessed significant inhibition in Clostridium perfringens (320 and $640 \mathrm{MIC}$ ), Staphylococcus aureus (80 and 320 $\mathrm{MIC}$ ) and Pseudomonas aeruginosa (640 and $2560 \mathrm{MIC}$ ). Cupuassu extracts showed no effect on any bacteria. The use of açai extract products can be a sustainable, viable and an accessible alternative for antimicrobial treatment. New studies should be conducted to determine better results for acai herbals and new formulations of cupuassu extracts.

Key Words: Açai, antimicrobial, cupuassu, phytotherapy 


\section{INTRODUCTION}

Due to existing cases of antimicrobial resistance against a diverse number of bacteria, new alternatives to combat these pathogens are being investigated. In recent years, phytotherapy research has increased, opening a new possibility as a viable complementary treatment for bacterial infections (Arantes et al., 2014). Besides being a new solution against resistant pathogens, these agents are readily accepted, due to the fact that they are generally less toxic to the host organism and to the environment (Souza et al., 2013).

The Amazon Forrest has the largest plant diversity in the world with various plants with known antimicrobial properties (Suffredini et al., 2006; Ranilla et al. 2012). However, more than $80 \%$ of the plants still have to be studied and their medicinal properties elucidated (Silva \& Franco 2010). Açai (Euterpe oleracea Mart.) and cupuassu (Theobroma grandiflorum) are among the most studied plants in Brazil (Carvalho et al., 2009; Santos et al., 2011). Studies have demonstrated the versatility of producing different pharmaceutical compounds using these plants using raw material, due to the diversity of the existing active compounds (Hanada et al., 2010; Gonçalves et al., 2012).

Clostridium perfringens is a group of obligatory anaerobic bacteria highly pathogenic to both animal and humans. Due to the inadequate use of antimicrobials, cases of antibiotic resistance have been observed for tetracycline, clindamycin, lincomycin and erythromycin, worldwide (Gholamiandehkordi et al., 2009; Gamboa-Coronado et al., 2011). Escherichia coli is a bacteria of great medical importance as it is present in the normal flora of the gastrointestinal tract of the animals, causing different diseases. This species possesses great genetic plasticity and as such it can develop resistance to diverse antimicrobial drugs (Hoban et al., 2011; Tadesse et al., 2012). Pseudomonas aeruginosa is a bacteria that causes opportunistic infections, presenting diverse clinical manifestations in humans and animals, such as pneumonia, enteritis, otitis. This organism can present natural or acquired resistance to a great number of antibiotics used in clinical practices. (Neves et al., 2011). Staphylococcus aureus is a pathogen encountered on the skin and animal cavities and is also of great importance due to opportunistic infections that it may cause. It 
possesses a notable ability to develop resistance to medications shortly after it's used (Weese \& van Duijkeren, 2010).

The objective of this study was to evaluate the effectiveness of different formulations of phytotherapeutic agents as antimicrobials, produced from leaves, fruits and seeds from açai and cupuassu.

\section{MATERIAL AND METHODS}

The açai (Euterpe oleracea Mart.) leaves, fruits and seeds were collected at the Biological Science Institute of the Federal University of Para, city of Belem, Brazil in July 2014. The cupuassu (Theobroma grandiflorum) leaves, fruits, and seeds were collected at Ver-o-Peso Market, in the same city and time period. The material was identified by its standard botanical description (Henderson, 1995). After collection, the material was dried at room temperature and subsequently grounded in a mill. This was followed by inspection and removal of foreign bodies and the product was subsequently stored in a dark recipient, protected from light and hermetically sealed, up to the time to be used in the production of the extracts.
The hydroalcoholic extracts were obtained utilizing an amber flask and sealing all its lateral extensions with aluminum foil. Seventy-two grams of each plant part were placed in separate flasks with $720 \mathrm{ml}$ of $70 \%$ ethyl alcohol $(\mathrm{v} / \mathrm{v})$. Subsequently, the content was stored for 30 days in the refrigerator at $4^{\circ} \mathrm{C}$ and stirred periodically. This step was followed by a filtration with the aid of a vacuum pump and a funnel with filter paper into a Kitasato flask.

After obtaining the extracts, the same were concentrated with a rotary evaporator under reduced pressure at a temperature lower than $30^{\circ} \mathrm{C}$ and subsequently lyophilized. The amount of açai extract obtained from the leaves (EFoA), fruits (EFrA) and seeds (ESA) were: $4.24 \% ; \quad 4.08 \%$ and $4.34 \%$ respectively. For cupuassu, the amount of extract obtained from the leaves (EFoC), fruits (EFrC) and seed (ESC) were $4.01 \% ; \quad 3.87 \%$ and $4.38 \%$ respectively.

The extracs were diluted in distilled water at a concentration of $10 \mathrm{mg} / \mathrm{ml}$, according to Matos (1997) to determine the following metabolites: phenols, tannins and anthocyanins, anthocyanidins, flavonoids, catechins, leucoanthocyanidins, steroids, triterpenes, saponins, resins and alkaloids. The Folin-Ciocalteu assay was 
utilized to determine the dosage of phenolic compounds according to the methodology adapted from McDonald et al. (2001). The absorbance of the extracts was compared to the standard of gallic acid $(1 \mu \mathrm{g} / \mathrm{ml}$ a $50 \mu \mathrm{g} / \mathrm{ml})$.

The cytotoxic activity of the extracts was evaluated according to the adapted method from Meyer et al. (1982). Metanauplius eggs were placed in an aquarium with artificial seawater at $38 \mathrm{~g} / \mathrm{L}$, under constant aeration and controlled temperature $\left(28^{\circ} \mathrm{C}\right)$. The larvae hatched $48 \mathrm{~h}$ after incubation, and ten metanauplius were transferred to a 24-well plate containing the diluted extracts with DMSO $(1 \% \quad \mathrm{v} / \mathrm{v})$ in concentrations varying from 31.75 to $8000 \mu \mathrm{g} / \mathrm{ml}$. The negative control group was prepared with only artificial seawater plus DMSO $(1 \% \mathrm{v} / \mathrm{v})$, and quinidine sulfate was used for the positive control. All tests were done in triplicates. After $24 \mathrm{~h}$ of contact, the number of live larvae was counted and the larvae that remained immobile after more than $15 \mathrm{sec}$ of agitating the plate were considered dead. From this value the lethal concentration (LD50) was calculated. The toxicity criteria of the extracts was established according to Déciga-Campos et al. (2007) with values of $>1000 \mu \mathrm{g} / \mathrm{mL}$ (non-toxic), $\geq 500 \leq$
$1000 \mu \mathrm{g} / \mathrm{mL}$ (weekly toxic) and $<500$ $\mu \mathrm{g} / \mathrm{mL}$ (toxic).

The antioxidant activity was determined according to Blois (1958). The samples at various concentrations (10 to 640 $\mu \mathrm{g} / \mathrm{mL}$ ) were added to a $152 \mu \mathrm{M}$ solution of 1,1-diphenyl-2-picrylhydrazyl (DPPH) in methanol. After incubation at $37^{\circ} \mathrm{C}$ for $30 \mathrm{~min}$, the absorbance of each solution was determined in spectrophotometer at $517 \mathrm{~nm}$. The antioxidant activity of the samples was expressed as $I_{50}$ (inhibitory concentration), which was defined as the concentration, in $\mu \mathrm{g} / \mathrm{m}$, of the sample required to inhibit the formation of DPPH radicals by $50 \%$. In this experiment, ascorbic acid was used as positive control.

All microorganisms were obtained from the American Type Culture Collection (ATCC), two Gram-positives strains, Clostridium perfringens (ATCC 12919) and Staphylococcus aureus (ATCC 29213) and two Gram-negatives, Escherichia coli (ATCC 25922) and Pseudomonas aeruginosa (ATCC 27853).

All bacteria were inoculated in $\mathrm{BHI}$ agar and incubated at $37^{\circ} \mathrm{C}$ for $24 \mathrm{~h}$. After which, subculturing was done with $50 \mu \mathrm{l}$ of the initial inoculum that was transferred to Mueller-Hinton broth, which was incubated at $37^{\circ} \mathrm{C}$ for $1 \mathrm{~h}$ until a discrete turbidity was observed: 
corresponding to $0.5 \mathrm{McF}$ arland turbidity

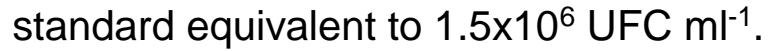
The agar diffusion test was done according to the method described by Karaman et al. (2003). With the aid of a sterile swab, the microbial inoculum was streaked onto the surface of the MullerHinton agar. The agar was poured at a depth of $4 \mathrm{~mm}$ within a Petri dish. Filter paper discs of $6 \mathrm{~mm}$ in diameter were impregnated with $10 \mu \mathrm{l}$ of extract. Using the serial dilution method, a total of eight different concentrations

(10$2.560 \mu \mathrm{g} / \mathrm{ml}$ ) of the plant extracts were obtained. The disks were deposited at a distance of $30 \mathrm{~mm}$ from each other and the periphery of the petri dish to reduce overlaying of the inhibition zone. The negative controls were prepared utilizing the same solvents used to dissolve the extracts. For the positive control Ciprofloxacin (40 $\mu \mathrm{g} /$ disk $)$ and Gentamicin (30 $\mu \mathrm{g} /$ disk) were utilized. The plates were incubated at $37^{\circ} \mathrm{C}$ for $24 \mathrm{~h}$. Each test in this experiment was done in triplicates. The antimicrobial activity was evaluated by measuring the inhibition zone formed around the disks. The minimum inhibitory concentration (MIC) was defined as the lowest concentration of the extract able to cause the death of the inoculum.

The microbial susceptibility index (MSI) was adapted from Eloff (2004) method, to compare the relative susceptibility among the microbial strains. MSI values ranged from 0 (resistant to all extracts) to 100 (susceptible).

MSI $=100 \times$ number of extracts effective against each microbial strain Number of total products

\section{RESULTS AND DISCUSSION}

The study of the Amazonian flora with the aim of discovering new antimicrobial agents is of great importance. In vitro tests serves as a preliminary step for the validation of novel phytotherapy products, as they allow the characterization of possible active compounds present within the plants and the evaluation of their biological properties (Silva et al., 2006; Paulo et al., 2009).

In both extracts the presence of the following metabolites were detected: phenols, tannins, steroids, triterpenes, resins, catechins, saponins and alkaloids. However, leucoanthocyanidins were not detected by the tests used. In the açai extract, anthocyanins and anthocyanidins were detected, however these compounds were not find in measurable quantities in the extracts produced from cupuassu. The data observed is consistent with what is available in the recent literature (Galotta 
\& Boaventura, 2005; Rodrigues et al., 2006; Carvalho et al., 2009; Rodrigues et al., 2010; Sousa et al., 2011). The total phenol value in gallic acid equivalents of the extracts from the leaves, fruits and seed from the açai plant were: $78.2 \pm 0.987 \mathrm{mg} \cdot \mathrm{g}^{-1} ; 318.2 \pm$ $0.755 \mathrm{mg} \cdot \mathrm{g}^{-1}$ and $185.2 \pm 0.91 \mathrm{mg} \cdot \mathrm{g}^{-1}$ respectively. Whereas, cupuassu

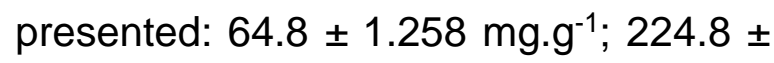
$0.58 \mathrm{mg} \cdot \mathrm{g}^{-1}$ and $148.8 \pm 0.413 \mathrm{mg} \cdot \mathrm{g}^{-1}$ respectively.

Phenolic compounds are natural antimicrobials with a high level of antioxidants (Oliveira et al., 2008) where this activity is greater when the $\mathrm{pH}$ is above 5.0. The antimicrobial effect of tannins has been confirmed in several studies. Its activity is due to enzyme inhibition in a direct action to the membrane, competing for metallic ions, essential for microbial metabolism (Shohayeb et al., 2013), whereas the antimicrobial activity of sterols occurs due to the alteration in the $\mathrm{pH}$ of the media and the alkylation of important proteins of the microorganisms (Schinor et al., 2007). Anthocyanins are known for their medicinal properties, such as its antimicrobial properties due to their antioxidant action (Rocha et al., 2011). Saponins, catechins and triterpenes possess relative bactericidal activity, especially against Gram-positive bacteria (Avato et al., 2006; Castilhos et al., 2007; Mencherini et al., 2007). The açai pulp showed the lowest DPPH scavenging potential with $\mathrm{IC}_{50}$ values of $52.7 \mu \mathrm{g} / \mathrm{ml}$ (Table 1 ) followed by the açai seed extract with $\mathrm{IC}_{50}$ values of $64.8 \mu \mathrm{g} / \mathrm{ml}$. Ascorbic acid (Control) exhibited an $\mathrm{IC}_{50}$ of $2.1 \mu \mathrm{g} / \mathrm{ml}$. Polyphenols have been associated with the anti-oxidant activity in fruits and vegetables, including açai and cupuassu, the flavonoids were found to be the major polyphenols in these plants. Many studies have demonstrated that flavonoids have strong anti-oxidant activities and others biological properties (Kang et al., 2010). In these plants, this compound is found primarily within the pulp of the fruit/plant. Other polyphenols that are also responsible for antioxidant activity are tannins and lignins (Gülçin, 2012).

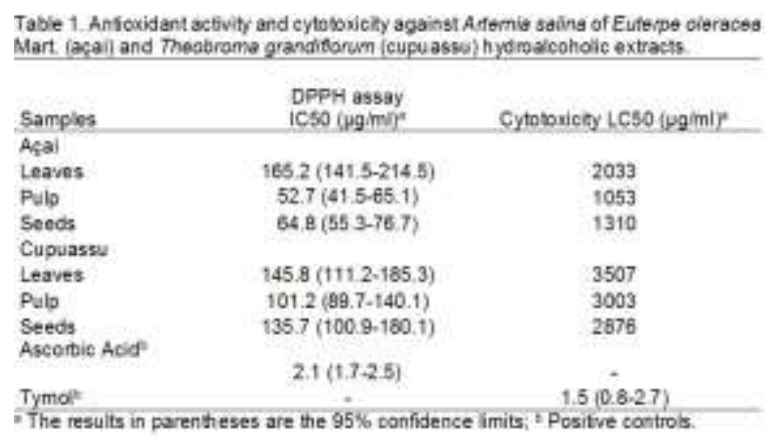

To establish the toxicity of $A$. annua, the lethal-dose test against $A$. salina was used as a highly reliable assay to 
determine the toxicity of microbes to the tested material. $S$.

phytotherapeutics agents (Fernández-

Calienes Valdés et al., 2009). The brine shrimp bioassay is a simple, rapid and low cost test that can be performed in vitro (Lieberman, 1999). It is important to analyze the toxicity of new therapeutic agents to verify the possible side effects when the product is tested in vivo. The results of the toxicity test are shown in Table 1. None of the extracts were toxic with values exceeding $1000 \mu \mathrm{g} / \mathrm{ml}$.

The antimicrobial activity of the plant extracts is shown in Table 2 . The extracts produced from the açai fruits and seeds, demonstrated antimicrobial activity against $C$. perfringens, $S$. aureus and $P$. aeruginosa. However, the extract produced from the açai leaves presented antimicrobial activity only against $S$. aureus. The extracts produced with the different parts of the cupuassu were not effective against any bacteria. None of the products had any effect against $E$. coli.

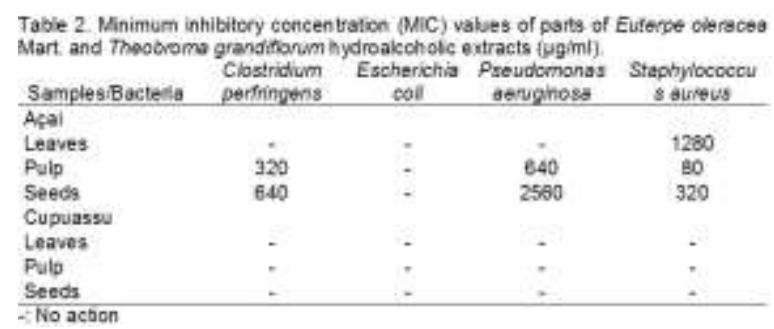

MSI values were useful in evaluating the susceptibility of the different strains of aureus (ATCC 29213) strain was found to be the most susceptible organism (MSI of 50) (Table 3). On the other hand, E. coli (ATCC 25922) showed to be resistant to all products.

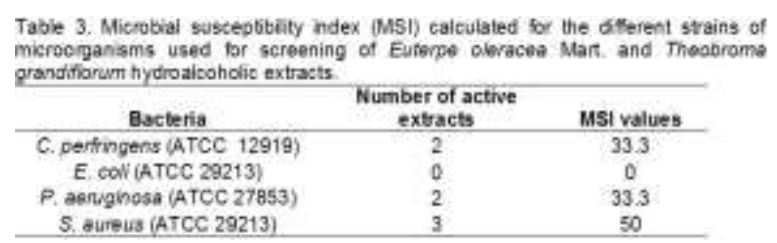

Araújo et al., (2013) demonstrated that extracts from the seed of the açai inhibit the growth of $S$. aureus. MelhorançaFilho \& Pereira, (2012) studied the antimicrobial activity of the oils produced from the açai fruit and observed antimicrobial activity against $S$. aureus. This bacteria is highly sensitive to antibiotics and substances with a similar mode of action, and as such, it can be used as a biological indicator for substances with potential antimicrobial activity (Oliveira et al., 2008). However, there are a few reports of the germicidal action of the extracts produced from the açai plant against gram-negative organisms. It is believed that this occurs due to the more complex structure and a greater lipid content of the cell wall of the plant, which could make the bacteria more resistant to phytochemicals (Efstratioi et al., 2012). 
Although Silva et al., (2014) analyzed the bactericidal effectiveness of plants from the Brazilian Caatinga Biome and observed that when these products were diluted in water there were no bactericidal action against $E$. coli and Enterobacter sp. and low effectiveness against Actinobacter sp. and Krebisiella sp., when the same material was diluted in ethyl-alcohol, antimicrobial activity was demonstrated to all microorganisms. But, this procedure can only be done in vitro, because the diluent is toxic to experimental animals (Nogueira et al., 2014). In our work the açai leave extract acted only on $S$. aureus, possibly due to the high sensitivity of the bacteria to its germicidal agents. This also occurred at low concentrations of the biocompounds, with the germicidal activity in this part of the plant. To increase the amount of phenolic compounds such as flavonoids and anthocyanins, and consequently improve the germicidal activity could be done by performing a cold digestion of the leaves in methanol (Rodrigues et al., 2006).

Cupuassu is one of the most studied plant in the pharmaceutical industry, mainly for the production of nutraceutical capabilities (Carvalho et al., 2009). However, there are no scientific studies that aimed to demonstrate its antimicrobial, activity. Thus, the present data is the first evidence study attempting to demonstrate their dosedependent activity against a range of potentially harmful bacteria. The phytochemical characteristics showed that the produced extracts from açai did not possess some of the important natural antimicrobial compounds such as anthocyanins. Besides this, the FolinCiocalteu test showed a low total phenol content. The cupuassu seed possesses anthocyanin and anthocyanins, compounds not found in the present test. This may be due to the extraction method utilized, where acidified methanol (methanol:acetic acid $=99: 1$ ) should have been utilized instead of hydro alcohol (ethyl alcohol : water = 70:30) (Pugliese, 2010). Fermenting cupuassu before the extraction with methanol $70 \% \quad(\mathrm{v} / \mathrm{v})$ can free more phenolic content, principally flavonoids, which are compounds with antimicrobial properties which may cause an oxidation of the cell wall of the microorganisms (Genovese \& Lannes, 2009). For the pulp of the fruit, it is recommended that freshly prepared pulp be used as it preserves a greater quantity of ascorbic acid, an element that possess a high antioxidant potential but is scarce in 
cupuassu in comparison with other tropical fruits (Maiai et al., 2010).

\section{CONCLUSIONS}

The use of açai plant extract can be a sustainable, viable and accessible alternative for antimicrobial treatment, however new studies should be performed to improve the present results. New formulations of cupuassu should also be investigated.

\section{REFERENCES}

ARANTES, A.V.; ANDRADE, M.C.; BARACHO, N.C.D.V. Estudo da Atividade Antimicrobiana das Folhas de Jatrophacurcas L. frente ao Staphylococcus aureus e Escherichia coli. Revista Ciências em Saúde, v.3, p.18-24, 2014.

ARAÚJO, M.; SILVA, C.F.C.; SOUZA, R.M. et al. Atividade antimicrobiana de óleos extraídos de açaí e de pupunha sobre 0 desenvolvimento de Pseudomonas aeruginosa e Staphylococcus aureus. Bioscience Journal, v.29, p.985-990, 2013.

AVATO P.; BUCCI R.; TAVA A. et al. Antimicrobial activity of saponins from Medicago sp.: structure-activity relationship. Phytotherapy Research v. 20, 454-457, 2006.

\section{BLOIS}

MS.

Antioxidant activity determination by the use of a stable free radical. Nature v. 181, p. 1199-1200, 1958.

CARVALHO, A.V.; GARCIA, N.H.P.; FARFÁN, J.Á. et al. Caracterização de concentrado e isolado proteico extraído de sementes de cupuaçu (Theobroma grandiflorum,
Schum). Brazilian
Journal of Food Technology, v. 12, p. 01-08, 2009.

CASTILHOS, T.S.; GIORDANI, R.B.; HENRIQUES, A.T. et al. Avaliação in vitro das atividades antiinflamatória, antioxidante e antimicrobiana do alcalóide montanina. Revista Brasileira de Farmacognósia, v. 17, p. 209-214, 2007.

DÉCIGA-CAMPOS, M.; RIVERO-CRUZ, I.; ARRIAGA-ALBA, M. et al. Acute toxicity and mutagenic activity of Mexican plants used in traditional medicine. Journal of Ethnopharmacology, v. 110, n.2, p. 334-342, 2007.

EFSTRATIOU, E.; HUSSAIN, A.I.; NIGAM, P.S. et al. Antimicrobial activity of Calendula officinalis petal extracts against fungi, as well as Gram-negative and Gram-positive clinical pathogens. Complementary Therapies in Clinic Practices, v. 18, p. 173-176, 2012.

FERNÁNDEZ-CALIENES VALDÉS, A; MENDIOLA MARTÍNEZ, J; MONZOTE FIDALGO, $\mathrm{L}$ et al. Evaluación de la toxicidad de extractos de plantas cubanas con posible acción antiparasitaria utilizando larvas de Artemia salina L. Revista Cubana de Medicina Tropical, v. 61, p. 254-258, 2009.

GALOTTA, A.L.Q.A.; BOAVENTURA, M.A.D. Chemical constituents from roots and leaf stalks of açai (Euterpe precatoria Mart., Arecaceae). Química Nova, v. 28, p. 610-613, 2005.

GAMBOA-CORONADO, M.D.M.; MAUINCHAUSTEGUI, S.; RODRÍGUEZCAVALLINI, E. Caracterización molecular y resistencia antimicrobiana de aislamientos de Clostridium perfringens de diferentes orígenes en Costa Rica. Revista de Biologia Tropical, v. 59, p. 1479-1485, 2011. 
GENOVESE, M.I.; LANNES, S.C.D.S. Comparison of total phenolic content and antiradical capacity of powders and" chocolates" from cocoa and cupuassu. Food Science and Technology, v. 29, p. 810-814, 2009.

GHOLAMIANDEHKORDI,

A.; EECKHAUT, V.; LANCRIET, A. et al. Antimicrobial resistance in Clostridium perfringens isolates from broilers in Belgium. Veterinary Research Communication, v. 33, p. 1031-1037, 2009.

GONÇALVES, G.; SANTOS, N.P.; SREBERNICH, S.M. Antioxidant and antimicrobial activities of propolis and açai (Euterpe oleracea Mart) extracts. Revista de Ciências Farmacêuticas Básicas e Aplicadas, v. 32, p. 349-356, 2012.

GÜLÇIN I. Antioxidant activity of food constituents: an overview.Archs Toxicol 2012; 86: 345-391.

HANADA, R.E.; POMELLA, A.W.V.; COSTA, H.S. et al. Endophytic fungal diversity in Theobroma cacao (cacao) and $T$. grandiflorum (cupuaçu) trees and their potential for growth promotion and biocontrol of black-pod disease. Fungi Biology, v. 114, p. 901-910, 2010.

HENDERSON, A. The palms of the Amazon. University Press, Oxford; 1995. 388p.

HOBAN, D.J.; NICOLLE, L.E.; HAWSER, S. et al. Antimicrobial susceptibility of global inpatient urinary tract isolates of Escherichia coli: results from the Study for Monitoring Antimicrobial Resistance Trends (SMART) program: 20092010. Diagostic Microbiology and Infection Disease, v. 70, p. 507-511, 2011.

KANG, J; LI, Z.; WU, T. et al. Antioxidant capacities of flavonoid compounds isolated from açai pulp
(Euterpe oleracea Mart.). Food Chemistry, v. 122, p. 610-617, 2010.

KARAMAN, I.; ŞAHIN, F.; GÜLLÜCE, M. et al. Antimicrobial activity of aqueous and methanol extracts of Juniperus oxycedrus $L$. Journal of Ethnopharmacology, v. 85, p. 231-235, 2003.

Lieberman M. A brine shrimp bioassay for measuring toxicity and remediation of chemicals. Journal of Chemistry Educucation, v. 76, p. 1689-1690, 1999.

MAIAI, G.M.S.G.A.; SOUSAII, P.H.M.; CORREIA, R.W.F.J.M. et al. Atividade antioxidante e correlações com componentes bioativos de produtos comerciais de cupuaçu. Ciência Rural, v. 40, p. 1636-1642, 2010.

MATOS, F.J.A. Introdução à fitoquímica experimental. 2 ed. EUFC: Fortaleza, 1997. 141p.

MCDONALD, S.; PRENZLER, P.; ANTOLOVICH, M. et al. Phenolic content and antioxidant activity of olive extracts. Food Chemistry, v. 73: p. 7384, 2001.

MELHORANÇA FILHO, A.L.; PEREIRA, M.R.R. Atividade antimicrobiana de óleos extraídos de açaí e de pupunha sobre o desenvolvimento de Pseudomonas aeruginosa e Staphylococcus aureus. Bioscience Journal, v.28, p.598-603, 2012.

MENCHERINI, T.; PICERNO, P.; SCESA, C. et al. Triterpene, antioxidant, and antimicrobial compounds from Melissa officinalis. Journal of Natural Products, v. 70, p. 1889-1894, 2007.

MEYER, B.N.; FERRIGNI, N.R.; PUTNAM, J.E. et al. Brine shrimp: a convenient general bioassay for active plant constituents. Planta Medica, v. 45, n. 5, p.31-34, 1982.

NEVES, P.R.; MAMIZUKA, E.M.; LEVY, C.E. et al. Pseudomonas aeruginosa 
multirresistente: um problema endêmico no Brasil. Jornal Brasileiro de Patologia Médica e Laboratorial, v. 47, p. 409-420, 2011.

NOGUEIRA, L.F. Evaluation of antibacterial, antifungal and modulatory activity of methanol and ethanol extracts of Padina sanctae-crucis. African Health Science, v. 14, p. 372-376,2014.

OLIVEIRA, I.; SOUSA, A.; FERREIRA, I.C. et al. Total phenols, antioxidant potential and antimicrobial activity of walnut Juglans regia L. green husks. Food Chemistry Toxicological, v. 46, p. 2326-2331, 2008.

PAULO, P.T.C.; DINIZ, M.D.F.; MEDEIROS, I.A.D. et al. Phase I clinical toxicological assays of a complex herbal medicine (Schinus terebinthifolius Raddi, Plectranthus amboinicus Lour and Eucaliptus globulus Labill). Revista Brasileira de Farmacognosia, v. 19, p. 68-76,2009.

PUGLIESE, A.G. Compostos fenólicos do cupuaçu (Theobroma grandiflorum) e do cupulate: Composição e possíveis benefícios (Dissertação, Universidade de São Paulo). Faculdade de Ciencias Farmaceuticas. Program de PósGraduação em Ciencias Farmaceuticas. 2010. 146p.

RANILLA, L.G.; APOSTOLIDISE, S.K. Antimicrobial activity of an Amazon medicinal

(Chancapiedra)(Phyllanthus niruri L.) against Helicobacter pylori and lactic acid bacteria. Phytotherapy Research, v. 26, p. 791-799, 2012.

Rocha MS, Figueiredo RWD, MoreiraAraújo RSDR. Teor de vitamina $\mathrm{C}$, flavonóides, antocianinas, ß-caroteno e licopeno do bureré (Brosimum gaudichaudii tréc.). Nutrire 2011; 36: 4444.

RODRIGUES, E.; DUARTE-ALMEIDA, J.M.; PIRES, J.M. Perfil farmacológico e fitoquímico de plantas indicadas pelos caboclos do Parque Nacional do Jaú (AM) como potenciais analgésicas. Parte I. Revista Brasileira de Farmacognósia, v. 20, p. 981-991, 2010.

RODRIGUES, R.B.; LICHTENTHÄLER, R.; ZIMMERMANN, B.F. et al. Total oxidant scavenging capacity of Euterpe oleracea Mart.(açai) seeds and identification of their polyphenolic compounds. Journal of Agricultural Food Chemistry, v. 54, p. 4162-4167, 2006.

SANTOS, R.L.; GUIMARÃES, G.P.; NOBRE, M.S.C. et al. Análise sobre a fitoterapia como prática integrativa no Sistema Único de Saúde. Revista Brasileira de Plantas Medicinais, v. 13, p. 486-91,2011.

SCHINOR, E.C.; SALVADOR, M.J.; ITO, I.Y. et al. Evaluation of the antimicrobial activity of crude extracts and isolated constituents from Chresta scapigera. Brazilian Journal of Microbiology, v. 38, p. 145-149, 2007.

SHOHAYEB, L.M.; ABDEL-HAMEED, E.; BAZAID, S. Antimicrobial activity of Tannins and extracts of different parts of Conocarpus erectus. Internacional Journal of Pharma and Bio Science, v. 3, p. 544-553, 2013;

SILVA, J.M.; FRANCO, E.S. Florística de espécies arbóreo-arbustiva do subbosque com potencial fitoterápico em fragmento florestal urbano no município de Camaragibe, Pernambuco, Brasil. Revista Caminhos da Geografia, v. 11, p. 179-194, 2010.

SILVA, MI.G.; GONDIM, A.P.S.; NUNES, I.F.et al. Utilização de fitoterápicos nas unidades básicas de atenção à saúde da família no município de Maracanaú (CE). Revista Brasileira de Farmacognósia, v. 16, p. 455-462, 2006. 
SILVA, V.F.; FRANCO, I.;

DAMASCENO, T.E.F. et al. Antimicrobial potential of ethanol extracts of plants against gram-negative bacilli isolated from cervicovaginal mucosa of sheep bred in the region of Petrolina-PE. Semina:

Ciências

Agrarária, v. 35, p. 883-890, 2014.

SOUSA, M.S.B.; VIEIRA, L.M.; SILVA, M.D.J.M. et al. Caracterização nutricional e compostos antioxidantes em resíduos de polpas de frutas tropicais. Ciência e Agrotecnologia, v. 35, p. 554-559, 2011.

SOUZA, C.M.P.; BRANDÃO, D.O.; SILVA, M.S.P. et al. Utilização de Plantas Medicinais com Atividade Antimicrobiana por Usuários do Serviço Público de Saúde em Campina GrandeParaíba. Revista Brasileira de Plantas Medicinais, v. 15, p. 188-193, 2013.

SUFFREDINI, I.B.; PACIENCIA, M.L.B.; VARELLA, A.D. et al. Antibacterial activity of Brazilian Amazon plant extracts. Brazilian Journal of Infectious Disease, v. 10, p. 400-402, 2006.

TADESSE, D.A.; ZHAO, S.; TONG, E. et al. Antimicrobial drug resistance in Escherichia coli from humans and food animals, United States, 19502002. Emerging Infectous Disease Journal, v. 18, p. 741-749, 2012.

WEESE, J.S.; VAN DUIJKEREN, E. Methicillin-resistant Staphylococcus aureus pseudintermedius in veterinary medicine. Veterinary Microbiology, v. 140, p. 418-429, 2010. 